\title{
Theoretical Aspects Of Career Patterns Under The Organization And Individual Career Management Perspectives
}

\author{
Olgerta Visi, MSc., PhD Candidate \\ Agricultural University of Tirana, Faculty of Agribusiness and Economics, \\ Lecturer, Faculty of Economics, UT, Albania
}

doi: 10.19044/esj.2016.v12n1p501 URL:http://dx.doi.org/10.19044/esj.2016.v12n1p501

\begin{abstract}
Nowadays, substantial changes have taken place in work reality, having a considerable impact on the career management prospects. Scenarios such as restructuring, delayering, downsizing of the business organizations, alongside the technological developments have inevitably affected the career management reality. The twenty first century career is no longer a linear process, confined to the organization's borders, the individuals are taking command, and the required approach is to be more flexible and adaptive in order to develop the indispensable skills and knowledge to meet the aimed goals (Hall, 1996). Discussing in terms of having an everlasting career is becoming irrelevant, instead finding opportunities to improve the professional expertise and life-long learning, is an issue of concern for the career management prospects from both perspectives. The organization is no more concerned, in a selfless and/or patriarchal sense, for the future development of its employees. The competencies are the only safe channels into sustaining marketability and employability in the fluctuant labor market. Career management is a highly delicate subject in need of special care accordingly; as the individual targets not only material gratification, but also spiritual replenishment, meanwhile the organizations aim at gaining competitive advantage in this rapidly changing work environment.

The paper will delve upon some of the most conspicuous theoretical career management approaches with regard to the organizational and the individual spectrums, identifying the respective new developments, vital not only to the professionals but to the practitioners interested in the issue and those who wish to harvest another updated perspective on the subject matter.
\end{abstract}

Keywords: Labor market, career management, competency, organizational spectrum. 


\section{Introduction}

Living in the 21-st century and confronted to a multitude of perspectives over choosing the right career path, the numerous schools and the varieties of career types make it uterly difficult to gasp the very essence of what a real professional career is like? What does it mean to succeed in one's career? How to hike towards the right path and what ensures us the choosen one is the right one? These concerns and similar others have undoubtedly distresed each of us more than once. Times have changes, so has the way careers unfold, similarily the approaches into paving the right course of career have also evolved. The very best thing is that neither of the carrer paths, being traditional, classic to modern ones 'don't get it wrong' Besides depicting a particular time-frame over which a certain typology has had priority over the other, these career realities entertwine so glamorously that is viable and doable to live in 2015 and choose the approach that best fits your aims, having the due possiblity to resul sucessful. The only 'if' is applying the right method to one's objectives and capacities.

Nowardays we are confronted to a multitude of technological and economic changes, consequently the nature of careers and the way individuals pursue their careers has changed (Sullivan, Carden \& Martin, 1998). The highly dynamic work environment, the access to the technological innovation options seem to facilitate the work process and this is a fact, but it has simultaneously brought about a high level of complexity to our lives. (Zhu, Wolff, Hall, Heras, Gutierres \& Kram, 2013).

Under these present day scenarios, restructuring, delayering, downsizing, flattening, the business organizations need to improve their organizational management, in order to attain and sustain competitive advantage over time and managing people is one of the key managerial duties (Larsen \& Brewster, 2003). The majority of the companies consider career management a vital part of HRM practice, assisting their employees to manage careers (Cappellen \& Janssens, 2010; Sturges, Conway, Guest \& Lifefooghe, 2005), as they aim to retain them to a long-term employment, therefore they become highly preoccupied in career management approaches towards ensuring the long-term availability of skilled and competent employees to reach business goals (Appelbaum, Ayre \& Shapiro, 2002; De Vos, Dewettinck \& Buyens, 2008). The organization career management facilitates the employee development as well as their performance (Lewis \&Arnold, 2012; Appelbaum et al., 2002).

The individual on the other hand, living in the information technology age, possess all the due means to develop themselves their career. Individual career management (also referred to as career self-management) has been noted as important to employee's career success (De Vos \& Soens, 2008; Weng \& McElroy, 2010). Employees who concentrate on career self- 
management usually tend to be more proactive compared to those who do not take such approach to their career management (King, 2004; Raabe, Frese \& Beehr, 2007). Proactive behaviors of employees support both individual and organizational success. (Bjorklund, Bhatli \& Laakso, 2013; Converse, Pathak, DePaul-Haddock, Gotlib \& Merbedone, 2012; Crant, 2000).

The main objective of the paper is rendering a tableau on the theoretical aspects of career, reckoned from the individual and the organizational perspective. An effort to present the respective advantages and limitations, providing the due prior information in order to facilitate the career plan. The paper will be based on two perspectives, the organizational and the individual.

\section{What does a career depict?}

There is a multitude of perspectives taken into account to define the term career. The term derives from the Latin carriera and French carrier meaning road or racing track; a quick course of action, being of people, horses, hawks and/or celestial objects (Merriam Webster Unabridged Dictionary, 2015). From Latin carrara, means road for vehicles. The term implies the line the individual follows, the path that has a direction and a purpose. In the early nineteenth century, the term took the connotations employed today and since then, refers the key characteristics of the Western society. The first use of the word is known around the year 1534 .

To the majority of us, a 'career' is distinguishable from a 'job', because when we say 'career' we awaken the image of a stable advancement, considerably logical up the organizational hierarchy (Hall and Hall, 1986). It does not simply specify what the individual does for a living, but depicts what the individual has done, does and can do in the future, hence the notion of career includes the dimension of time, as its second dimension. On a commonplace perspective, when we daily talk about having a career, generally is assumed to refer to the working career, to what we do for a living or what we have written in our curriculum vitae. Thus, a mere definition of 'career' may include '... working positions sequence along the entire life of the individual "(London \& Stumpf, 1982) or" ... evolving sequences of experiences of a person's work over time. "(Arthur, Hall \& Lawrence, 1989).

In the organizational career context, the career concept implies a relationship between the employers and employees, during a specified timespan. Thereon, steering up the image of development planning, in often cases of a hierarchical character, which suggests a logical sequence of events and work experiences. The career does not just denote a job; it is something that embraces the notions of development and logical progress, furthermore not 
confined to this. The career concept is much wider than the career definitions related exclusively to work, which have dominated the management mentality and practice. From the organizational-economic perspective, for example, careers can be seen as 'the means through which the human capital augments, is cultivated through a life of education and experience' (Bartley and Robitschek, 2000).

On the other hand, from the individual perspective, the career can be considered as the sequencing of efforts to maximize self-interest, through successive attempts to gain power, status or influence (Kaufman, 1960). To the individual, careers can carry a multitude of meanings. To some, it constitutes the means through which the vital economic needs are met; others only through a consolidated career attain a sense of self-identity, social status, social value or self-fulfillment (Arthur et al, 1989). In other cases, the careers can symbolically represent the dream of an individual's life (Levinson et al, 1978), offering him guidance, meaningfulness and purposefulness in performing their daily activities.

The current use lies in a number of areas, due to different purposes, from different perspectives, having various implications. These uses create the due premises to a variety of contextual definition, which consequently make it difficult for career to be defined as a universal designated concept, but as a series of constructs. These multi-implications purvey career to variegated meanings of the concept, although it may result in making the term vague and even ambivalent and requires high caution in interpreting each particular use of the word.

Nowadays, we have acknowledged the evolving character of career, it bears the essential quality: it is extended in time, but always temporary. As such, it is not a static "object", deprived of evolving, but it is necessarily a phenomenon configured for continuity. Consequently, to the individual perspective the meaning of career is undergoing a construction and reconstruction process, in the light of personal and organizational development and interchange.

\section{Study objective}

The paper objective is the theoretical approach to the problem in focus: depicting the current reality of the professional career management, viewed from the individual and organization outlook, evidenced by the conditioning factors and drawing conclusions for future approaches to career management.

\section{Methodology}

The methodology utilized in the paper serves the study objective. The paper focus consists in the theoretical analysis of the career management 
patterns from the individual and organization prospects, apropos of the methodological approach is based on:

Table work: the research is focused on consulting the relevant literature, consisting of scientific publications, reports, various researches and studies, serving as the basis of providing the theoretical grounds. The authors' selection is made considering the similarities as well as the differentiations in handling the issue. The study considered literature in English language. The efforts to find the appropriate literature in Albanian language, (research was waged in the Albanian Academy of Sciences and the Albanian National Library) which would obviously serve of aid to amass an Albanian specific perspective, resulted unsuccessful due to the lack of literature in Albanian language. This result, considerably underpins the importance of the paper, being if not the first, among the first considerations in the field from an Albanian author.

\section{Career management from the organization perspective}

Organizational career management includes the organization's activities for employees’ career development, differing from organization to organization. (Baruch and Peiperl, 2000). It's the organizations who determine the talents, capabilities, skills of the employees, providing accordingly organizational practices in employees' career development (Verbruggen et al., 2007). One of the core effective career management techniques is career planning management, and particularly when the organization culture and/or philosophy aim at internally promoting the growth of managerial talent. This and other techniques as training, mentoring, educational opportunities, performance appraisals etc., are advantageous instruments that may be adopted by companies to help employees to manage their careers (Crawshaw, 2006; Lewis \& Arnold, 2012).

By establishing a career management structure, the organizations are enabled to relocate the most valuable employees in the most subtlety planned positions, so that they can specifically get acknowledged to the strategic and long term plans of the organization, cultivate the indispensable knowledge and skills and be positioned in the managerial structures or, in the case of professionals, to enhance their status. Consequently, a well-structured career management allows the organizations to manage a group of individuals with high potential and enable them to perform at full efficiency their tasks, move up the managerial levels and comply with the future organization needs (Herriot, 1992).

Providing the employees with the expected capacity building and training needs, naturally augments their career satisfaction (Chiaburu, Diaz, \& De Vos, 2013; Lewis \& Arnold, 2012). Moreover, career satisfaction is 
intrinsically related to a considerably high level with organizational commitment. Various studies have confirmed that organizational career management strengthens the organizational commitment (Bambacas, 2010; Hsiao \& Chen, 2012; Morrow, 2011; Shibin, 2006). If we view the organization -employee relationship from the Rausseau's (1995) psychological contract, if utilizing the organization career management instrument we can simultaneously respond to the organization's implied expectations and the individual's expectations, both sides standing in the center of the process, resulting in a win -win scenario. The psychological contract is a powerful instrument to develop a sense of loyalty: it 'fastens' the people upon the organization (Rousseau, 1995). This is particularly the case when the employee benefits, besides the monetary compensation (exp. the housing loans, the opportunities on acquiring shares, etc.), the spiritual gratification, generating the willingness to establish a long-term relationship, thereof seeing their career become a convergence of the individual and the organizational objectives (Atkinson, 2002). By expressing a psychological identification to their job (Zhou \& Li, 2008), the job involvement levels are considerably enhanced. In their studies, Zhou and Li (2008) assert that there is a positive, impeccable relationship between the organizational career management and job involvement. The employees who are notably jobinvolved put a lot of effort into achieving the organizational objectives (Rotenberry \& Moberg, 2007). Having the same objectives and jointly achieving them, amounts to the fact-result that the development of the individual and the company career plans are aligned, thus contributing to building a greater cohesion among them.

Career planning is a part of organizational career management (Baruch, 2003; Tzabbar, Vardi \& Baruch, 2003). Career planning has a key tool as, if being implemented by the due tactics, following a well-elaborated step by step plan, setting the right, timely goals, assessing the strengths and weaknesses respectively (Hall, 1996) will purvey a good chance of succeeding, under normal circumstances.

Organizations already do accept that in this highly volatile market reality they are no longer making efforts to provide the due conditions to create a long-term career, it is irrelevant; but instead suggest providing the conditions into which the individuals can enhance their skills, improve the core competencies and thereof increase their market value.

The very safe move the organizations can make is improving their competitiveness by implementing the due strategies in order that the career management practices they would undertake may result successful (Gustavsson, 2012; Muňoz-Bullon \& Sanchez-Bueno, 2010). The fact is that traditional career management which is directed by organizations has shifted to career self-management (Barnett \& Bradley, 2007; Wickramasinghe \& 
Jayaweera, 2011), and this is a reality we have to accept and need to get accustomed.

\section{Career management from the individual perspective}

The changes in the work reality have opened new horizons to the individual career management, defined as the process by which individuals develop, implement and monitor their career paths, goals and strategies. Basically, career is a property of the individual (Baruch, 2006). Career management is the process by which the individuals can make informed decision regarding their work lives (Greenhaus, Callanan and Godshalk, 2000). The attention hub has shifted from the organization to the individual and the new prospects have made increasingly influencing the individual's role upon the career perspectives. Currently, the twenty first century career is not a linear process, confined to the organization's borders, the individuals are taking command, and the required approach is to be more flexible and adaptive in order to develop the indispensible skills and knowledge to meet the aimed goals (Hall, 1996).

According to Amundson et al (2002) the employees must ensure that, even though they might not progress within their organization, they must have their jobs to provide them with professional challenges and know-how so that they remain engaged, skillful in their profession and marketable. Thus, the individual career management results to be a central aspect of the individual choices in life. It is only through carefully developing the competencies, being technical or interpersonal, (McQuade, \& Maguire, 2005) the individual might promote employability (De Vos, De Hauw \& Van de Heijden, 2011). The competencies are the only safe channels into sustaining marketability and employability in the fluctuant labor market. The development of life-long transferable skills would enhance the occupational expertise and professionalism, consequently the control over their career, which in turn leads to career satisfaction (King, 2004), being a crucial factor to individual and organizational success (Joo and Park, 2010). Under the circumstances, the individuals who feel successful are motivated to further contribute to their intellectual and/or professional cultivation. The individuals who lack career satisfaction are more prone to leave their profession (Mariani, 2007). Greenhaus et al. (2000, p. 85) discuss individual career strategies and emphasize the role of taking an initiative. Participating in training or other capacity building programs, updating their actual knowledge from time to time and creating a lifelong learning culture are selfmanagement strategies that enhance the individual and environment awareness, clarifying their goals and contributing to a better career decisionmaking (Weng and McElroy, 2010). That is the reason why, particularly the highly educated people are capable and able to manage their own careers 
(Dittmann, 2009; Mihail, 2008). This continuous improvement would definitely affect positively the potential future promotion chances. Recapping the individual perspective, we may state that it is the individuals' duty to scrutinize over the organization career management policies and afterwards draw valuable conclusions on pursuing the due approach into managing their own career, being in or out of the current organization environment, having as a compass their potential.

\section{The intertwining among the dual perspectives}

We can continue to perceive organizations as secure social institutions, but the new reality of organizational career, to a considerable part, entails that organizations do not symbolize anymore the security, stability and sustainability. The career is becoming boundaryless, (Arthur \& Rousseau, 1996). A career for life is being replaced by the opportunities for a constant individual development and the promise on future rewards based on loyalty; thus replacing the short-term contracts in exchange to performance upon the agreed objectives. The organization is no more concerned, in a selfless and/or patriarchal sense, for the future development of its employees, or at least this is the image outlined to the individuals in the light of the current career management. The reality of work is proposing new realities on career advancement. The focus of attention has shifted from the organization to the individual and the social-constructivist perspective on career is becoming increasingly dominant.

The organizations strive to cultivate the concept of the career guiding the individual into finding the internal and external ways to develop and advance in one's career.

The dynamics of the new reality suggests that the organizational career from both perspectives, the organization and the individual simultaneously, outline a number of assumptions that underpin the importance of developing a consistent 'portfolio of skills' (Williams and Hall, 1997). The career progress is not necessarily connected to the hierarchical uninterrupted employment position or organization. A good CV may not contain an impressive list of titles and positions in an ascending progression and/or seniority, but if it includes a variety of roles within the same workplace and out-of-work activities, demonstrating vertical as well as lateral movements in ones' career in numerous organizations, providing evidence of flexibility within the workplace and among various functions, it is worth considering. Thereon, studies have suggested that nowadays employers talk about providing opportunities to enhance marketability and employability (Viney, Adamson \& Doherty, 1995). This must be the main operation ground from both perspectives when in pursue of career success. 


\section{Conclusion}

In the recent decades, dramatic changes have taken place, which have had a considerable impact on the career prospects. A multitude of contextual developments led to what Kidd (1996) has described as "the new career realities". Processes such as: the companies' reduction, internal restructuring, de-stratification often resulted in increased cases of dismissal, suspension, fragmentation and diversification of the working groups and consequently the career 'paths'. These transformations are attributed to the profound changes occurring in the employment context, further mentioning the pressure due to the economy globalization, the growing diversity in workforce and the advances in technology (Sullivan, 1999). As a result, job security has declined. We can no way expect a 'timeless' employment and fixed structures or unchanged positions. Discussing in terms of having an everlasting career is becoming irrelevant, instead finding opportunities to improve the professional expertise and life-long learning, is an issue of concern for the career management prospects. Having a stable career is less likely to be encountered, instead flexibility and adaptability are the substitutes.

The innovative notions of marketability and employability have become acceptable features of career management (King, Burke \& Pemberton, 2005). As a result, new rules, expectations and conditions have emerged, creating new experiences for the employees, so that they can manage their own careers. (Hall \&Hall, 1986). Autonomy and idiosyncratic routes (Greenhaus, Callanan and Godshalk, 2010) are becoming highly palpable in both the organizational and individual perspective to career management.

If we are to divide the 'shares' in career management approaches, we may state that the organizations are no longer the guard of the individual's career, the organization may efficiently determine the master-plan basis of career management, the general strategies and set the sails to faithfully implement it; meanwhile the individuals, if complying with the organization policies, can further proceed more in-depth onto managing their careers by specifically targeting their capacity niches.

The paper is a modest endeavor onto the highly demanding subject, pinpointing only onto some of the characteristics of this dual career management perspective, future considerations on the subjects are plausible and welcomed in addressing either specific variables to the individual and/or organizational career management perspectives, or country idiosyncratic outlooks therein. 


\section{References:}

Appelbaum, S.H., Ayre, H. \& Shapiro, B.T. Career management in information technology: A case study. Career Development International, 7(3), 142-158. 2002.

Amundson, N. E., Arthur, M. B., \& Parker, P. Merging Two worlds: Linking Occupational and Organizational Career Counseling. The Australian Journal of Career Development, 11(3), 2002.

Arthur, M. B., \& Rousseau, D. M. The boundaryless career. New York: Oxford University Press. 1996.

Arthur, M. B., Hall, D. X, \& Lawrence, B. S. The handbook of career theory. Cambridge, UK: Cambridge University Press. 1989.

Atkinson, C. Career management and the changing psychological contract. Career Development International, 7(1), 14-23. 2002.

Bambacas, M. Organizational handling of careers influences managers' organizational commitment. Journal of Management Development, 29(9), 807-827. 2010.

Bartley, D. F., \& Robitschek, C. Career exploration: A multivariate analysis of predictors. Journal of Vocational Behavior, 56, 63-81. 2000.

Barnett, B.R. \& Bradley, L. The impact of organisational support for career development on career satisfaction. Career Development International, 12(7), 617-636. 2007.

Baruch, Y.: Career development in organizations and beyond: Balancing traditional and contemporary viewpoints, Human Resource Management Review, 16, 125-138, 2006.

Baruch, Y. Career systems in transition: A normative model for organizational career practices. Personnel Review, 32(2), 231-251. 2003.

Baruch, Y., \& Peiperl, M. A. Career management practices: An empirical survey and theoretical implications. Human Resource Management (US), 39(4), 347-366. 2000.

Bjorklund, T., Bhatli, D. \&Laakso, M. Understanding idea advancement efforts in innovation through proactive behavior. Journal of Research in Marketing and Entrepreneurship, 15(2), 124-142. 2013.

Cappellen, T. \& Janssens, M. Enacting global careers: Organizational career scripts and the global economy as co-existing career referents. Journal of Organizational Behavior, 31, 687-706. 2010.

Chiaburu, D.S., Diaz, I. \& De Vos, A. Employee alienation: Relationships with careerism and career satisfaction. Journal of Managerial Psychology, 18(1), 4-20. 2013.

Converse, P.D., Pathak, J., DePaul-Haddock, A.M., Gotlib, T. \&Merbedone, M. Controlling your environment and yourself: Implications for career success. Journal of Vocational Behavior, 80, 148-159. 2012. 
Crant, J.M. Proactive behavior in organizations. Journal of Management, 26(3), 435-462. 2000.

Crawshaw, J.R. Justice source and justice content: Evaluating the fairness of organizational career management practices. Human Resource Management Journal, 16(1), 98-120. 2006.

De Vos, A., Dewettinck, K. \& Buyens, D. To move or not to move? The relationship between career management and preferred career moves. Employee Relations, 30(2), 156-175. 2008.

De Vos, A., De Hauw, S. \& Van de Heijden, B.I.J.M. Competency development and career success: The mediating role of employability. Journal of Vocational Behavior, 79, 438-447. 2011.

De Vos, A. \& Soens, N. Protean attitude and career success: The mediating role of self-management. Journal of Vocational Behavior, 73, 449-456. 2008.

Dittmann, W. A case study of degree completion graduates' transition from technician to manager. Unpublished Phd Thesis, University of Minnesota, United States. 2009.

Greenhaus, J. H., Callanan, G. A., \& Godshalk, V. M. Career management (3rd ed.). Fort Worth: Dryden. 2000.

Greenhaus, J.H., Callanan, G.A., and Godshalk, V.M. Career Management $4^{\text {th }}$ edition. Sage Publications. 2010.

Gustavsson, M. Learning and propensity for changing the job situation during downsizing. Journal of Workplace Learning, 24(7/8), 497-508. 2012. Hall, D. Career Development, Boston University Press, Boston, MA. 1996. Hall and Hall. Applying Career Concepts in Career Management, Coventry University; Canadian College Journal, McGinnis. 1986.

Herriot, P. The Career Management Challenge: Balancing Individual and Organizational Nee\& Sage, London. 1992.

Hsiao, J.M. \& Chen, Y.C. Antecedents and consequences of job satisfaction: A case of automobile component manufacturer in Taiwan. International Journal of Organizational Innovation, 5(2), 164-178. 2012.

Joo, B. \& Park, S. Career satisfaction, organizational commitment, and turnover intention: The effects of goal orientation, organizational learning culture and developmental feedback. Leadership \& Organizational Development Journal, 31(6), 482-500. 2010.

Kaufman, H. The forest ranger. Baltimore, Md.: Johns Hopkins Press. 1960. Kidd, J. M. Career planning within work organisations. In A. G. Watts, B. Law, J. Killeen, J. M. Kidd \& R. Hawthorn (Eds.), Rethinking Careers Education and Guidance. Theory, Policy and Practice (pp. 142-154). London: Routledge. 1996.

King, Z. Career self-management: Its nature, causes and consequences. Journal of Vocational Behavior, 65, 112-133. 2004. 
King Z, Burke S., Pemberton J. The 'bounded' career: An empirical study of human capital, career mobility and employment outcomes in a mediated labor market. Human Relations, 58 (8), 981 -1007. 2005.

Larsen, H.H.\& Brewster, C. Line management responsibility for HRM: What is happening in Europe? Employee Relations, 25(3), 228-244. 2003.

Levinson, D J et al. The Seasons of a Man's Life. Knopf, New York. 1978.

Lewis, S. \& Arnold, J. Organizational career management in the UK retail buying and merchandising community. International Journal of Retail \& Distribution Management, 40(6), 451-470. 2012.

London, M., \& Stumpf, S. A. Managing careers. Reading, MA: AddisonWesley. 1982.

Mariani, B.S. The effect of mentoring on career satisfaction of registered nurses and intent to stay in the nursing profession. Unpublished doctoral dissertation, Widener University, United States. 2007.

McQuade, E. \& Maguire, T. Individuals and their employability. Journal of European Industrial Training, 29(6), 447-456. 2005.

Mihail, D.M. Graduates' career orientations and strategies in corporate Greece. Personnel Review, 37(4), 393-411. 2008.

Morrow, P.C. Managing organizational commitment: Insights from longitudinal research. Journal of Vocational Behavior, 79, 18-35. 2011.

Muňoz-Bullon, F. \& Sanchez-Bueno, M.J. Downsizing implementation and financial performance. Management Decision, 48(8), 1181-1197. 2010.

Raabe, B., Frese, M. \&Beehr, T.A. Action regulation theory and career selfmanagement. Journal of Vocational Behavior, 70, 297-311. 2007.

Rotenberry, P.F. \& Moberg, P.J. Assessing the impact of job involvement on performance. Management Research News, 30(3), 203-215. 2007.

Rousseau, D. Psychological contracts in organizations. Thousand Oaks, CA: Sage. 1995.

Shibin, M. Organizational career management: Researching at managerial philosophy level. Canadian Social Science, 2(5), 31-37. 2006.

Sturges, J., Conway, N., Guest, D. \& Lifefooghe, A. Managing the career deal: The psychological contract as a framework for understanding career management, organizational commitment and work behavior. Journal of Organizational Behavior, 26, 821-838. 2005.

Sullivan, S. E. The Changing Nature of Careers: A Review and Research Agenda. Journal of Management, 25(3), 457-484. 1999.

Sullivan, S.E., Carden, W.A. \& Martin, D.F. Careers in the next millennium: Directions for future research. Human Resource Management Review, 8(2), 165-185. 1998.

Tzabbar, D., Vardi, Y. \& Baruch, Y. Organisational career management in Israel. Career Development International, 8(2), 88-96. 2003. 
Verbruggen, M., Sels, L. \& Forrier, A. Unraveling the relationship between organizational career management and the need for external career counseling. Journal of Voccational Behavior 71, 69 -83. 2007.

Viney, C; Adamson, S J \& Doherty, N. 'Organisations' Expectations and Career Management of Fast Track Recruits'. Paper Presented to The New Deal in Employment Conference, City University Business School, December. 1995.

Weng, Q. \& McElroy, J.C. Vocational self-concept crystallization as a mediator of the relationship between career self-management and job decision effectiveness. Journal of Vocational Behavior, 76, 234-243. 2010. Wickramasinghe, V. \& Jayaweera, M. Career management strategies among IT professionals in offshore outsourced IT firms in Sri Lanka. Journal of Management Development, 30(9), 914-926. 2011.

Williams, A.G. and Hall, K.J. Creating Your Career Portfolio: At a Glance Guide. Upper Saddle River: Prentice-Hall. 1997.

Zhou, W. \& Li, B. Study on the relationship between organizational career management and job involvement. Frontiers of Business Research in China, 2(1), 116-136. 2008.

Zhu, G., Wolff, S.B., Hall, D.T., Heras, M.L., Gutierres, B. \&Kram, K. Too much or too little? A study of the impact of career complexity on executive adaptability. Career Development International, 18(5), 457-483. 2013. https://unabridged.merriam-webster.com- last checked, August 2015. 